\title{
Mutational analysis of the PITX2 coding region revealed no common cause for transposition of the great arteries (dTGA)
} Nadja Muncke1, Beate Niesler1 ${ }^{1}$, Ralph Roeth ${ }^{1}$, Karin Schön ${ }^{1}$, HeinzJuergen Rüdiger ${ }^{2}$, Elizabeth Goldmuntz ${ }^{3}$, Judith Goodship ${ }^{4}$ and Gudrun Rappold*1

\begin{abstract}
Address: ${ }^{1}$ Institut für Humangenetik, Universität Heidelberg, INF 366, 69120 Heidelberg, Germany, ${ }^{2}$ Abteilung für Kardiologie, Kinderklinik Heidelberg, INF 153, 69120 Heidelberg, Germany, ${ }^{3}$ Division of Cardiology, Department of Pediatrics, University of Pennsylvania, School of Medicine, Philadelphia, Pennsylvania 19104, USA and ${ }^{4}$ Institute of Human Genetics, International Center for Life, Central Parkway, Newcastle upon Tyne, NE1 3BZ, UK

Email: Nadja Muncke - nadja_muncke@med.uni-heidelberg.de; Beate Niesler - beate_niesler@med.uni-heidelberg.de; Ralph Roeth - ralph_roeth@med.uni-heidelberg.de; Karin Schön - karin_schoen@med.uni-heidelberg.de; Heinz-Juergen Rüdiger - HeinzJuergen_Ruediger@med.uni-heidelberg.de; Elizabeth Goldmuntz - goldmuntz@email.chop.edu; Judith Goodship - j.a.goodship@ncl.ac.uk; Gudrun Rappold* - gudrun_rappold@med.uni-heidelberg.de

* Corresponding author
\end{abstract}

Published: 12 May 2005

BMC Medical Genetics 2005, 6:20 doi:10.1 186/147/-2350-6-20

This article is available from: http://www.biomedcentral.com//47/-2350/6/20

(C) 2005 Muncke et al; licensee BioMed Central Ltd.

This is an Open Access article distributed under the terms of the Creative Commons Attribution License (http://creativecommons.org/licenses/by/2.0), which permits unrestricted use, distribution, and reproduction in any medium, provided the original work is properly cited.
Received: 27 August 2004

Accepted: 12 May 2005

\begin{abstract}
Background: PITX2 is a bicoid-related homeodomain transcription factor that plays an important role in asymmetric cardiogenesis. Loss of function experiments in mice cause severe heart malformations, including transposition of the great arteries (TGA). TGA accounts for $5-7 \%$ of all congenital heart diseases affecting 0.2 per 1000 live births, thereby representing the most frequent cyanotic heart defect diagnosed in the neonatal period.
\end{abstract}

Methods: To address whether altered PITX2 function could also contribute to the formation of dTGA in humans, we screened 96 patients with ITGA by means of dHPLC and direct sequencing for mutations within the PITX2 gene.

Results: Several SNPs could be detected, but no stop or frame shift mutation. In particular, we found seven intronic and UTR variants, two silent mutations and two polymorphisms within the coding region.

Conclusion: As most sequence variants were also found in controls we conclude that mutations in PITX2 are not a common cause of dTGA.

\section{Background}

With a frequency of up to $1 \%$, congenital heart disease represents one of the most common major congenital anomalies [1-3]. Transposition of the great arteries (TGA) accounts for $5 \%$ of all congenital heart defects [4]. TGA manifests during the early fifth week of development affecting the septation of the common outflow tract into aorta and pulmonary arteries, and has been suggested to represent a laterality defect of the heart [5]. The more common dTGA (dextro-looped TGA) represents a complete inversion of the great vessels (atrioventricular concordance and ventriculoarterial discordance). In the less 
common ITGA (laevo-looped TGA), both atrioventricular and ventriculoarterial discordance is present. Despite the high prevalence and clinical importance of TGA, we are just beginning to unravel the etiology of this heterogeneous disease. Up to now, three genes have been suggested to be involved in the etiology of dTGA in humans: PROSIT240, a novel TRAP240-like gene, has been recently isolated and several mutations are suggested to be responsible for a subset of TGA patients [6]. Isolated mutations in ZIC3 [7] and CFC1 (human CRYPTIC gene) [8,9] have also been detected in patients with TGA. ZIC3 and CFC1 have been shown before to be involved in laterality defects in humans $[8,10]$. However the total number of mutations detected so far within these three genes is not sufficient to explain the high incidence of dTGA and point towards strong heterogeneity.

As cardiac neural crest cells contribute to the formation of the outflow septum that divides the common outflow tract, an association between neural crest disturbance and TGA has been suggested. Extirpation experiments in chick could show that neural crest cells contribute to normal aorticopulmonary septation. Deletion of those cells causes malformation of the aorticopulmonary septum resulting in common arterial outflow channels or transposition of the great arteries [11,12]. Pitx2, a bicoid-related homeodomain transcription factor involved in eye, heart and craniofacial development and establishment of leftright asymmetry, is expressed in several tissues of the developing mouse embryo including neural crest derived organs [13]. In humans, PITX2 haploinsufficiency causes Axenfeld-Rieger Syndrome (ARS), an autosomal dominant disorder involving ocular, dental and umbilical defects [14] and, in some patients with unknown mutations, also cardiac defects [15,16]. Most interestingly,
Pitx2 loss of function experiments in mice cause severe cardiovascular defects including transposition of the great arteries [17-20]. Kioussi et al. reported that Pitx2\% mice, that survive up to E15, invariantly exhibit major cardiac outflow tract abnormalities, amongst which 30\% show incomplete septation of the great arteries, that may develop with double outlet right ventricle (DORV) or transposition of the great arteries [20]. Deletion of the Dvl2 gene [21], which is regulated by the same pathway as Pitx2, leads to the same severe outflow tract malformations, indicating a strong implication of this pathway in the outflow tract phenotype. These lines of evidence prompted us to investigate whether PITX2 mutations in humans can also contribute to the etiology of TGA.

\section{Methods \\ Human subjects and genomic DNA}

Peripheral-blood samples were taken from healthy individuals and patients with simple dTGA after informed consent had been obtained, after approval by the institutional review board of ethics of the Medical Department of the University of Heidelberg and the Newcastle and North Tyneside Health Authority Joint Ethics Committee. Genomic DNA was prepared using the Puregene DNA Isolation Kit (Gentra, Inc., USA).

\section{PCR and mutation screening}

Amplifications were performed using the High Fidelity System (Roche) according to the manufacturer's protocol. Primers were designed according to the PITX2 sequence gene bank accession number AF238048 and respective sequences are given in table 1 . Mutation screening was performed using denaturing high performance liquid chromatography (DHPLC). A WAVE DNA-Fragment Analysis System (Transgenomic Inc., Cheshire) was used.

Table I: Primer pairs used for mutation analysis, covering the coding region of PITX2.

\begin{tabular}{|c|c|c|c|c|}
\hline exon & primer name & sequence $5^{\prime}>3^{\prime}$ & $\mathbf{T}_{\mathbf{A}}{ }^{\circ} \mathbf{C}$ & reference \\
\hline 2 & $\begin{array}{l}\text { PITX2-exon2for: } \\
\text { PITX2-exon2rev: }\end{array}$ & $\begin{array}{l}\text { tag tct cat ctg agc cct gc } \\
\text { gcg att tgg ttc tga ttt cct }\end{array}$ & 60 & Ref: [25] this paper \\
\hline 3 & $\begin{array}{l}\text { PITX2-exon3bfor: } \\
\text { PITX2-exon3brev: }\end{array}$ & $\begin{array}{l}\text { ttg ctc ttt gtc cct ctt tct cct } \\
\text { cgg agt gtc taa gtt caa gca gca }\end{array}$ & 60 & this paper \\
\hline $4 a$ & $\begin{array}{l}\text { PITX2-exon4afor: } \\
\text { PITX2-exon4arev: }\end{array}$ & $\begin{array}{l}\text { ccg cct ctg gtt tta aga tg } \\
\text { gca aag acc ccc ttc ttc tc }\end{array}$ & 60 & this paper \\
\hline $4 b$ & $\begin{array}{l}\text { PITX2-exon4bfor: } \\
\text { PITX2-exon4brev: }\end{array}$ & $\begin{array}{l}\text { ctt gac act tct ctg tca gg } \\
\text { aag cgg gaa tgt ctg cag g }\end{array}$ & $60 / 56 / 52 *$ & Ref: [25] \\
\hline 5 & $\begin{array}{l}\text { PITX2-exon5for: } \\
\text { PITX2-exon5rev: }\end{array}$ & $\begin{array}{l}\text { cag ctc ttc cac ggc ttc t } \\
\text { ttc tct cct ggt cta ctt gg }\end{array}$ & 60 & Ref: [25] \\
\hline 6 & $\begin{array}{l}\text { PITX2-exon6for: } \\
\text { PITX2-exon6rev: }\end{array}$ & $\begin{array}{l}\text { gta atc tgc act gtg gca tc } \\
\text { agt ctt tca agg gcg gag tt }\end{array}$ & 65 & Ref: [25] \\
\hline
\end{tabular}

$\mathrm{T}_{\mathrm{A}}$ : Annealing temperature

* step down PCR was performed with three temperatures for 10/10/15 cycles. 


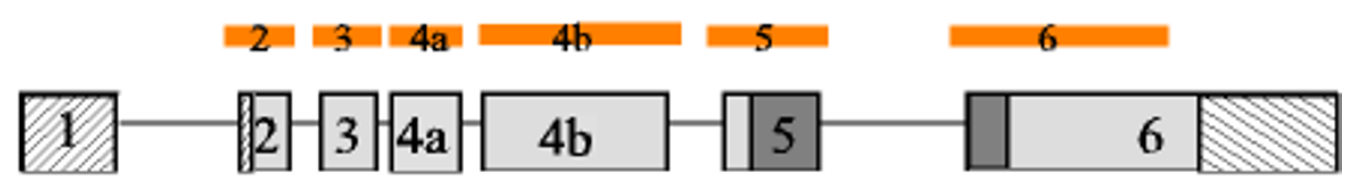

PITX2a

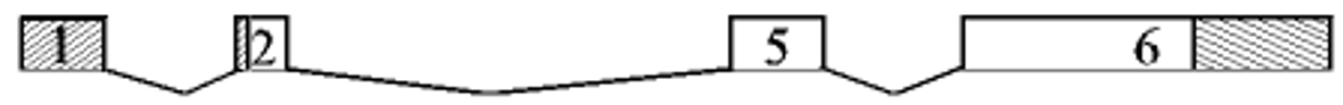

PITX2b

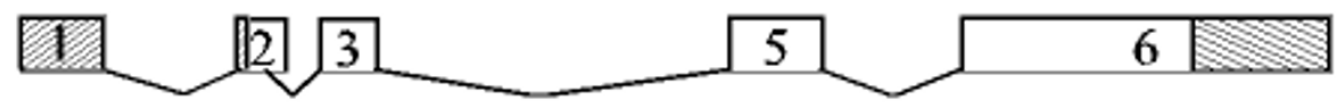

PITX2c

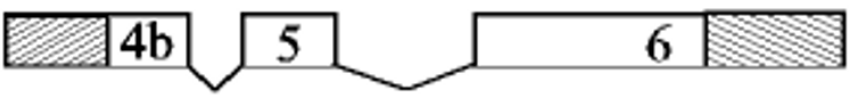

PITX2d

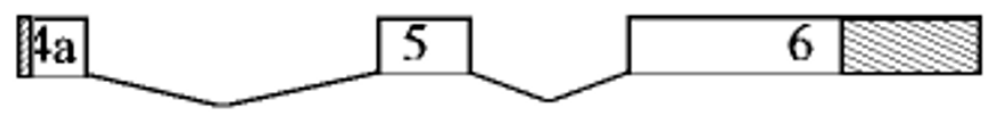

\section{Figure I}

Schematic diagram of PITX2 isoforms a, b, c and d. The genomic organization of the PITX2 gene is given on top, exons are numbered, 5' and 3' UTRs of the different possible transcripts are indicated by striped boxes and the homeodomain is shaded in dark grey. Modified from Cox et al, 2002 [24]. The regions of the PITX2 gene included in the mutational screening are indicated as orange bars at the very top of the scheme.

\section{Sequencing}

Sequencing was performed on a MegaBACE sequencer (Amersham Bioscience, Piscataway) using the DYEnamic $^{\mathrm{TM}}$ ET terminator Cycle Sequencing Kit following the manufacturer's protocol. Sequencing reactions were performed on both DNA strands. Sequences were analyzed using the Clustal program (German Cancer Research Center, Biocomputing Facility HUSAR, Heidelberg).

\section{Results and Discussion}

96 patients with dTGA were analyzed for mutations in PITX2 by DHPLC and direct sequencing. All coding exons of PITX2 (exon 2 to 6 , including both alternatively spliced exons $4 \mathrm{a}$ and $\mathrm{b}$ ) were amplified by intron-specific exonflanking primers to screen exon-intron junctions (table 1, figure 1). Non-coding regions (exon 1 and the 3'part of exon 6), intronic regions beyond the intronic sequences covered by the amplification, and promoter elements were not examined. We identified seven intronic and UTR variants, two silent mutations and two polymorphisms within the coding region. Most of these variants were found also in similar frequencies in 100 control individuals and are therefore unlikely to be of functional relevance. The missense mutation detected in exon $4 \mathrm{~b}$ (204C>A, P65T) most likely represents a polymorphic variant compared to the sequence in the database, as the heterozygous form was invariantly detectable in all tested patients and controls. This finding also excludes large deletions in the patients affecting the whole gene locus. Three intronic (IVS2+7A>G, IVS3+11G>T, IVS4a-62C>A) and one silent mutations (30G>C Ser10Ser) were not detectable in 100 controls. One variant in the 5'UTR (2$40 \mathrm{~T}>\mathrm{C}$ ) and one missense mutation (30C>T S27F) were only found once in control individuals (table 2).

We report on the mutation screening of PITX2, as we considered it to be an interesting candidate gene for TGA due 
Table 2: Summary of PITX2 sequence variations in the dTGA study cohort

\begin{tabular}{|c|c|c|c|c|}
\hline \multicolumn{3}{|l|}{ patients $(n=96)$} & \multicolumn{2}{|c|}{ controls } \\
\hline type of variation: & specific variation & variant frequency (\%) & number of controls & frequency $(\%)$ \\
\hline $\begin{array}{l}\text { intronic/UTR } \\
\text { variations: }\end{array}$ & $\begin{array}{l}2-40 T>C\left(5^{\prime} U T R \text { exon 2) }\right. \\
2-I 8 T>C \text { (5'UTR exon 2) } \\
\text { IVS2+7A }>G \text { (intron 2) } \\
\text { IVS2-I06C }>A \text { (intron 2) } \\
\text { IVS3+IIG }>T \text { (intron 3) } \\
\text { IVS4a+IIG (intron 4a) } \\
\text { IVS4a-62C }>A \text { (intron 4a) }\end{array}$ & $\begin{array}{c}10(10.4 \%) \\
0(0 \%) \\
1(1.04 \%) \\
17(17.7 \%) \\
1(1.04 \%) \\
30(31,25 \%) \\
1(1.04 \%)\end{array}$ & $\begin{array}{l}100 \\
100 \\
100 \\
100 \\
100 \\
100 \\
100\end{array}$ & $\begin{aligned} \text { I2 } & (12 \%) \\
\text { I } & (1 \%) \\
0 & (0 \%) \\
20 & (20 \%) \\
0 & (0 \%) \\
39 & (39 \%) \\
0 & (0 \%)\end{aligned}$ \\
\hline silent mutations: & $\begin{array}{l}30 \mathrm{G}>\mathrm{C}(\mathrm{S} \mid \mathrm{OS})(\text { exon } 2) \\
63 \mathrm{C}>\mathrm{T}(\mathrm{A} 2 \mathrm{IA})(\text { exon } 4 \mathrm{~b})\end{array}$ & $\begin{array}{l}\text { I (I.04\%) } \\
\text { I (I.04\%) }\end{array}$ & $\begin{array}{l}100 \\
100\end{array}$ & $\begin{array}{l}0(0 \%) \\
2(2 \%)\end{array}$ \\
\hline $\begin{array}{l}\text { polymorphism within } \\
\text { coding region: }\end{array}$ & $\begin{array}{l}30 \mathrm{C}>\mathrm{T}(\mathrm{S} 27 \mathrm{~F})(\text { exon } 3) \\
204 \mathrm{C}>\mathrm{A}(\mathrm{P} 65 \mathrm{~T})(\text { exon 4b) }\end{array}$ & $\begin{array}{c}0(0 \%) \\
96(100 \%)\end{array}$ & $\begin{array}{l}100 \\
100\end{array}$ & $\begin{array}{c}\mathrm{I}(1 \%) \\
100(100 \%)\end{array}$ \\
\hline
\end{tabular}

UTR: untranslated region

to its role in regulating asymmetric cardiac morphogenesis [22] and interesting data from mouse studies. Impaired Pitx2 function in mice leads to severe cardiac malformations [17-20]. It has been suggested that altered PITX2 expression in the outflow tract could underlie either TGA or DORV [22].

PITX2 comprises three major isoforms, formed by differential splicing or alternative promotor usage: PITX2a, $b, c$, as well as one minor isoform PITX2d (Fig 1). We have included all coding exons in our screening as all forms exhibit a differential expression pattern $[18,19]$. Pitx2c is of special interest, as only this isoform is asymmetrically expressed within the lateral plate mesoderm and the heart and governs asymmetric organ morphogenesis in a dosedependent manner $[23,19]$. Furthermore, the newly identified minor isoform, PITX2d, that in fact does not bind to DNA, was included in the study since it may influence expression levels of the other splice variants and also regulate the transcriptional activity of the major isoforms on protein level [24]. As only low amounts of PITX2 are required for normal cardiac development and as the different isoforms can possibly compensate for each other in some cell populations, it might require a combination of different sequence variants within different isoforms of the gene to dramatically reduce PITX2 function and therefore manifest a cardiac phenotype.

\section{Conclusion}

To address whether altered PITX2 function could also contribute to the formation of dTGA in humans, we screened the coding regions as well as exon-intron boundaries of the PITX2 gene for mutations in 96 patients with dTGA. The majority of detected variants, however, were also found in controls with comparable frequency. Three intronic and one silent mutation could not be detected in 100 controls. As they were only found once in the cohort of 96 patients and as none of the variants was found within the evolutionary conserved homeodomain, we consider them to be rare polymorphisms rather than functional mutations, although we cannot totally exclude the latter possibility. Further investigations will have to evaluate whether these sequence variants might change splicing processes. Due to the study design we can also not exclude mutations in the very 5'and 3' UTRs and within introns as well as the promoter regions of the gene. Nevertheless, we conclude that the detected mutations in PITX2 are not a common cause of dTGA.

\section{Competing interests}

The author(s) declare that they have no competing interests.

\section{Authors' contributions}

NM designed the study, BN participated in the mutation analysis and drafted the manuscript, RR and KS performed PCRs and sequencing reactions. HJR, JG and EG provided patient care and collected blood samples. GR was involved in study design and supervision and finalized the manuscript. All authors read and approved the final manuscript.

\section{Acknowledgements}

We would like to thank D. Driscoll, Children's Hospital of Philadelphia, for support in collecting DNA samples. N.M. was supported by the Landesgraduiertenförderung, Baden-Württemberg, Germany. 


\section{References}

I. Hoffman JI: Incidence of congenital heart disease: I. Postnatal incidence. Pediatr Cardiol 1995, 16:103-1 I3.

2. Hoffman Jl: Incidence of congenital heart disease: II. Prenatal incidence. Pediatr Cardiol 1995, I6:155-165.

3. Samanek M: Congenital heart malformations: prevalence, severity, survival, and quality of life. Cardiol Young 2000 I0(3): $179-185$

4. Fyler DC, Buckley LP, Hellenbrand WE, et al.: Report of the New England regional infant cardiac program. Pediatrics 1980 65(Suppl):375-46I.

5. Digilio MC, Casey B, Toscano A, Calabro R, Pacileo G, Marasini M, Banaudi E, Giannotti A, Dallapiccola B, Marino B: Complete transposition of the great arteries: patterns of congenital heart disease in familial precurrence. Circulation 2001, I 04(23):2809-28|4

6. Muncke $N$, Jung $C$, Rudiger $H$, Ulmer $H$, Roeth R, Hubert A, Goldmuntz E, Driscoll D, Goodship J, Schon K, Rappold G: Missense mutations and gene interruption in PROSIT240, a nove TRAP240-like gene, in patients with congenital heart defect (transposition of the great arteries). Circulation 2003, I 08(23):2843-2850.

7. Megarbane A, Salem N, Stephan E, Ashoush R, Lenoir D, Delague V, Kassab R, Loiselet J, Bouvagnet P: X-linked transposition of the great arteries and incomplete penetrance among males with a nonsense mutation in ZIC3. Eur J Hum Genet 2000, 8(9):704-708

8. Bamford RN, Roessler E, Burdine RD, Saplakoglu U, dela Cruz J, Splitt M, Towbin J, Bowers P, Ferrero GB, Marino B, Schier AF, Shen MM Muenke $M$, Casey $B$ : Loss-of-function mutations in the EGFCFC gene CFCI are associated with human left-right laterality defects. Nat Genet 2000, 26(3):365-369.

9. Goldmuntz E, Bamford R, Karkera JD, dela Cruz J, Roessler E, Muenke M: CFCI mutations in patients with transposition of the great arteries and double-outlet right ventricle. Am J Hum Genet 2002, 70(3):776-780.

10. Gebbia M, Ferrero GB, Pilia G, Bassi MT, Aylsworth A, Penman-Splitt M, Bird LM, Bamforth JS, Burn J, Schlessinger D, Nelson DL, Casey B: $\mathrm{X}$-linked situs abnormalities result from mutations in ZIC3. Nat Genet 1997, I 7(3):305-308

I I. Kirby ML, Gale TF, Stewart DE: Neural crest cells contribute to normal aorticopulmonary septation. Science 1983 220(460I): |059-106I.

12. Creazzo TL, Godt RE, Leatherbury L, Conway SJ, Kirby ML: Role of cardiac neural crest cells in cardiovascular development. Annu Rev Physiol 1998, 60:267-286.

13. Hialt TA, Semina EV, Amendt BA, Murray JC: The Pitx2 protein in mouse development. Dev Dyn 2000, 2 I 8(I): 195-200.

14. Semina EV, Reiter R, Leysens NJ, Alward WL, Small KW, Datson NA Siegel-Bartelt J, Bierke-Nelson D, Bitoun P, Zabel BU, Carey JC, Murray JC: Cloning and characterization of a novel bicoid-related homeobox transcription factor gene, RIEG, involved in Rieger syndrome. Nat Genet 1996, I 4(4):392-399.

15. Sadeghi-Nejad A, Senior B: Autosomal dominant transmission of isolated growth hormone deficiency in iris-dental dysplasia (Rieger's syndrome). J Pediatr 1974, 85(5):644-648.

16. Brooks JK, Coccaro PJ Jr, Zarbin MA: The Rieger anomaly concomitant with multiple dental, craniofacial, and somatic midline anomalies and short stature. Oral Surg Oral Med Oral Pathol 1989, 68(6):717-724.

17. Gage PJ, Suh H, Camper SA: Dosage requirement of Pitx2 for development of multiple organs. Development 1999 I 26(20):4643-465 I.

18. Kitamura K, Miura H, Miyagawa-Tomita S, Yanazawa M, Katoh-Fukui Y, Suzuki R, Ohuchi H, Suehiro A, Motegi Y, Nakahara Y, Kondo S, Yokoyama M: Mouse Pitx2 deficiency leads to anomalies of the ventral body wall, heart, extra- and periocular mesoderm and right pulmonary isomerism. Development 1999 I 26(24):5749-5758.

19. Liu C, Liu W, Lu MF, Brown NA, Martin JF: Regulation of left-right asymmetry by thresholds of Pitx2c activity. Development 200I I 28( I I):2039-2048.

20. Kioussi C, Briata P, Baek SH, Rose DW, Hamblet NS, Herman T, Ohg KA, Lin C, Gleiberman A, Wang J, Brault V, Ruiz-Lozano P, Nguyen HD, Kemler R, Glass CK, Wynshaw-Boris A, Rosenfeld MG: Identification of a Wnt/Dvl/beta-Catenin - > Pitx2 pathway medi- ating cell-type-specific proliferation during development. Cell 2002, I I I(5):673-685

21. Hamblet NS, Lijam N, Ruiz-Lozano P, Wang J, Yang Y, Luo Z, Mei L, Chien KR, Sussman DJ, Wynshaw-Boris A: Dishevelled 2 is essential for cardiac outflow tract development, somite segmentation and neural tube closure. Development 2002 I 29(24):5827-5838.

22. Franco D, Campione $M$ : The role of Pitx2 during cardiac development. Linking left-right signaling and congenital heart diseases. Trends Cardiovasc Med 2003, I3(4): I57-163.

23. Schweickert A, Campione M, Steinbeisser H, Blum M: Pitx2 isoforms: involvement of Pitx2c but not Pitx2a or Pitx2b in vertebrate left-right asymmetry. Mech Dev 2000, 90(I):4I-5I.

24. Cox CJ, Espinoza HM, McWilliams B, Chappell K, Morton L, Hjalt TA Semina EV, Amendt BA: Differential regulation of gene expression by PITX2 isoforms. J Biol Chem 2002, 277(28):2500 I-250 I0.

25. Martin DM, Probst FJ, Fox SE, Schimmenti LA, Semina EV, Hefner MA, Belmont JW, Camper SA: Exclusion of PITX2 mutations as a major cause of CHARGE association. Am J Med Genet 2002, | | | :27-30.

\section{Pre-publication history}

The pre-publication history for this paper can be accessed here:

http://www.biomedcentral.com/1471-2350/6/20/prepub
Publish with BioMed Central and every scientist can read your work free of charge

"BioMed Central will be the most significant development for disseminating the results of biomedical research in our lifetime. "

Sir Paul Nurse, Cancer Research UK

Your research papers will be:

- available free of charge to the entire biomedical community

- peer reviewed and published immediately upon acceptance

- cited in PubMed and archived on PubMed Central

- yours - you keep the copyright 